\title{
Practices, Governance, and Politics: Applying MacIntyre's Ethics to Business
}

\author{
Matthew Sinnicks \\ University of Hertfordshire
}

\begin{abstract}
This paper argues that attempts to apply Alasdair MacIntyre's positive moral theory to business ethics are problematic, due to the cognitive closure of MacIntyre's concept of a practice. I begin by outlining the notion of a practice, before turning to Moore's attempt to provide a MacIntyrean account of corporate governance. I argue that Moore's attempt is mismatched with MacIntyre's account of moral education. Because the notion of practices resists general application I go on to argue that a negative application, which focuses on regulation, is more plausible. Large-scale regulation, usually thought antithetical to MacIntyre's advocacy of small-scale politics, has the potential to facilitate practice-based work and reveals that MacIntyre's own work can be used against his pessimism about the modern order. Furthermore, the conception of regulation I defend can show us how management is more amenable to ethical understanding than MacIntyre's work is often taken to imply.
\end{abstract}

KEY WORDS: MacIntyre, practices, management, regulation, virtue-ethics

\section{INTRODUCTION}

$\mathrm{D}^{\mathrm{s}}$ ESPITE MACINTYRE'S ATTACK on what he calls the 'character' of the Manager (MacIntyre 2007: 25-35), and his overwhelmingly critical view of corporate modernity more generally, ${ }^{1}$ MacIntyre's work has proved to be influential among business scholars. Muirhead (2004) suggests that MacIntyre's concept of a practice offers the best account of the promise of work, Moore (2012) argues that MacIntyre's work provides a convincing diagnosis of the problems within capitalism, Du Gay (2000) describes MacIntyre as a source of inspiration for critical theorists of management, and Crawford (2009) acknowledges that MacIntyre's influence is felt throughout his popular paean to manual craft work. This influence is largely due to the richness of MacIntyre's concept of a 'practice' and the account of moral education it provides the basis for. Although MacIntyre himself is hostile to business, and indeed to the very notion of business ethics, his moral theory goes beyond recommending a particular conception of right action or of the virtues and promises to account for those intrinsically rewarding and enriching activities we encounter, including those within the workplace, and of how such activities, or 'practices' as MacIntyre calls them, enable virtue acquisition. Although MacIntyre's work provides what is, in my view, a compelling ethical theory, and one that is clearly relevant to the question of how businesses and agents within business organizations can 
be virtuous, his key concept of a practice resists the kind of uniform codification that a positive account of business ethics would require. It is incorrect to conclude that MacIntyre can have no application to substantive questions in business ethics, but nevertheless any application is likely to be more problematic than some of MacIntyre's allies have supposed.

I begin by outlining MacIntyre's concept of a practice. While management is almost certainly not a practice in MacIntyre's sense, institutionally sustaining practice-based communities is a practice-a practice which MacIntyre names 'politics.' I go on to outline the key features of the essential relationship between practices and institutions. This essential relationship might seem to give us grounds for believing that practice-based work can be achieved through implementing the right kinds of governance measures, but this is not so. I argue that Moore's (2012) attempt to formulate a MacIntyrean account of corporate governance fails to recognize the challenges posed by the need for engagement in practices, challenges which render Moore's aim deeply problematic. The cognitive closure of practices seriously threatens such positive general applications of MacIntyre's moral theory. I end by offering a more restrictive suggestion about how MacIntyre's ethics can be applied to business ethics, and argue that negative applications of MacIntyre's ethical theory can show how regulation, a notion normally considered antithetical, can be regarded as a facilitator of practice-based communities. Devising and implementing apt regulatory measures can thus be seen as a form of the meta-practice of politics and can, if my argument succeeds, show that even if MacIntyre's pessimism about modernity is warranted, there is space in MacIntyrean moral theory for managers who help to protect forms of human community.

\section{MACINTYRE'S ACCOUNT OF PRACTICES}

Though many readers will be familiar with MacIntyre's concept of a practice, as it has featured in a number of papers in this journal in recent years (including Moore 2005a, 2005b, 2012; Beadle and Knight 2012; Beabout 2012), it is a complex concept and one that is central to this paper, so I will begin by outlining it with the aim of clarifying both the concept itself and some of its implications for business ethics. For MacIntyre a practice is the first of three stages in his conception of a virtue, the second and third being the narrative unity of a human life and an account of what he calls a moral tradition respectively. ${ }^{2}$ So while there is more to virtues than practices, indeed virtues are ultimately grounded in distinctive human needs and capacities so that they contribute to our flourishing qua human beings (MacIntyre 1999, see especially chapter 7), MacIntyre holds that practices provide a basis for the virtues. MacIntyre uses the word 'practice' in a highly specific way:

By a 'practice' I am going to mean any coherent and complex form of socially established co-operative human activity through which goods internal to that form of activity are realized in the course of trying to achieve those standards of excellence which are appropriate to, and partially definitive of, that form of activity, with the result that human powers to achieve excellence, and human conceptions of the ends and goods involved, are systematically extended. (MacIntyre 2007: 187) 
Due to MacIntyre's commitment to the Aristotelian claim that the virtues allow us to live the good life, practices are closely related to MacIntyre's conception of human flourishing. Practices are not only intrinsically worthwhile, they are also perfective of those who engage in them. Practices then, are the 'schools' of the virtues. If MacIntyre is right, then in addition to the inherent dignity of, say, working to support one's family, work that is practice-based will further contribute both to the good of the agents who partake in it, and to our wider common good, which will be served by activities that are inherently morally educative.

MacIntyre illuminates his definition by giving some examples of what he takes to be practices. Architecture, chess, portrait painting, physics, football and farming are practices ${ }^{3}$ and are therefore both ends in themselves and conducive to virtue acquisition, while bricklaying, throwing or kicking a ball with skill, and planting turnips are not and so cannot (MacIntyre 2007: 187). While we might disagree with MacIntyre's own examples, we should be wary of applying the concept too generously. As MacIntyre says, "a practice, in the sense intended, is never just a set of technical skills, even when directed towards some unified purpose and even if the exercise of those skills can on occasion be valued or enjoyed for their own sake." (MacIntyre 2007: 193) So complexity is required not merely because it makes an activity more likely to be enjoyable, but rather because extremely simple activities cannot extend human capacities in such a way as to be morally significant. As an illustration of this point, consider Adam Smith's remarks on simple, repetitive work:

The man whose whole life is spent in performing a few simple operations . . . has no occasion to exert his understanding or to exercise his invention in finding out expedients for removing difficulties which never occur. He naturally loses, therefore, the habit of such exertion, and generally becomes as stupid and ignorant as it is possible for a human creature to become. (Smith 1999: 368)

'Simple operations,' which lack complexity, cannot possess genuine internal goods. They might be temporarily diverting, but they lack the additional richness required to be morally educative, which is a key feature of practices.

For MacIntyre, internal goods are those goods which cannot be achieved in any way other than engaging in the activity in question, and are to be contrasted with external goods, examples of which include power, prestige, and money. ${ }^{4}$ These external goods can all be sought and used virtuously, but they are not bases of virtue acquisition, on MacIntyre's view. Given that engaging in practices allows us to acquire the virtues, we do value them partly for this reason, but the notion of internal goods allows us to see that practices are not simply valuable for their consequences but also for their own sake (Knight 2007: 156). To genuinely engage in a practice is to be moved by the standards of excellence distinctive of that practice. Engaging in a practice is an end in itself, and internal goods, in this sense, are "those incommensurably different satisfactions which supervene upon excellence in carrying out the activities which are constitutive of the practice" (D'Andrea 2006: 269). Unlike internal goods, external goods can always be achieved in a variety of ways, and so are only contingently related to any particular activity and can be "defined independently of that activity" (Murphy 2003b: 162). Again unlike internal goods, 
external goods are characteristically always someone's property and possession (MacIntyre 2007: 188).

According to MacIntyre's account of moral education, it is the pursuit of internal goods that allows us to develop the virtues. For instance, one of the internal goods of portrait painting is that of attempting to capture the inner states or character of the subject in a way that goes beyond merely accurate representation of their appearance. Such an activity is an end in itself, but in order to truly excel at portrait painting a painter must have the humility to subordinate him or herself to the standards of excellence of the practice and to respect the achievements of the great portrait painters, such as Rembrandt and Kahlo. The portrait painter must also have the patience and self-discipline to continue to refine his or her skills, and the honesty and self-honesty to give and receive fair criticism. The goods internal to the practice thus provide the initial motivation for virtue acquisition. The virtues enable agents to achieve internal goods and to participate in the community of practitioners. In time the virtues come to be valued in themselves, and once properly acquired can be and are exhibited outside of the context in which they were learned.

This brings us to a final point about the nature of practices: the place a particular activity has within a particular community of practitioners, and therefore with a particular tradition of practice. MacIntyre claims that to "enter into a practice is to enter into a relationship not only with contemporary practitioners, but also with those who have preceded us in the practice" (MacIntyre 2007: 194). The great painters, the great physicists, and even the great athletes transform their disciplines, and these practices have histories characterized by systematic extensions of conceptions of ends and goods internal to those practices. When entering into a practice we must trust the judgments of others within the relevant community of practitioners. We must listen to their advice, and recognize that they possess expertise and an ability to judge that we do not. Clearly, not all judgments about internal goods are equal, and because goods internal to a practice can be experienced only by engaging in that practice, beginners are necessarily less qualified to judge than those who excel at the practice. We will return to this point below as it has important ramifications for the relationship between practices and the institutions that house them.

For MacIntyre the goods internal to practices can be fully known only by those who have experience of them, and only those fully engaged can know enough about a practice to pass judgment on when its historically established standards have been met or surpassed. In this sense, practices are cognitively closed-the inexperienced do not know enough about a practice to pass judgment on it, or on the success or otherwise of those who possess the relevant experience. While there are some more or less settled cases, it is therefore entirely conceivable that MacIntyre is wrong about particular examples of practices and non-practices. If turnip planting or tic-tac-toe eventually find advocates willing to argue that such activities are serious contenders for the status of 'practices,' scholars interested in MacIntyre's ethics will be forced to look again at those activities.

Given this cognitive closure, why is MacIntyre's concept of a practice interesting to ethicists? The answer to this question is that the concept offers the possibility of not simply taking an independently plausible ethical theory and applying it to dif- 
ferent ethically perplexing situations. It goes beyond applying a conception of good conduct to roles, organizational contexts, and forms of employment. Instead it offers the basis of an explanation of how such activities, that are rewarding in themselves, can allow us to develop the virtues. MacIntyre's concept of a practice has been of interest to scholars in a variety of fields. While some scholars have argued that particular jobs are practices, such as teaching (Dunne 2003), nursing (Sellman 2000), and journalism (Borden 2007), others have sought to apply the concept to business ethics more generally. A significant body of literature on MacIntyre's notion of a practice has been concerned to show that either management (Brewer 1997, Warren 1996) or business (Moore 2002) are the kinds of rich, intrinsically rewarding, virtue-inculcating activities deserving of the title 'practice.' Such scholars see in MacIntyre's work the potential for a deeper and richer understanding of contemporary work and of business ethics than is available elsewhere, despite MacIntyre's own pessimism about such matters. ${ }^{5}$

Because management is both pervasive within business organizations and inherently ethically complex, it is unsurprising that it has been the focus of attention from business ethicists looking to apply MacIntyre's moral theory. The key issue with any attempt to argue that management, or business more generally, is a practice is whether management possesses distinctive internal goods. Beadle has convincingly argued that business does not possess internal goods (Beadle 2008) and has also argued that any attempt to use MacIntyre's work to support an account of management will necessarily involve misappropriating MacIntyre due to his thorough-going anti-capitalism (Beadle 2002). Below I will suggest that we can still make sense of good management from a MacIntyrean perspective even if Beadle's arguments are correct.

Managers can of course be virtuous or vicious, and this will play an important role in determining how satisfying employees' working lives are, but this does not imply that management is a practice. The sheer variety of managerial roles and functions means that a general argument that management is a practice is unlikely to succeed. Sport is not a practice, but particular sports are. Some roles that fall under the heading of 'management' might prove to be practice-based. The problem for putative applications of MacIntyre's moral theory to business ethics is that there are so many relevant variables that a general, wide-ranging application will inevitably fail to capture them all. Of course, whether a particular activity is to be accounted a practice is a partly empirical matter, so for now we can simply note that compelling evidence for management's practice-status has not been forthcoming. Instead of focusing on the nature of managerial work per se, and whether it can be accounted a practice, my aim is to show that MacIntyre's ethical theory can be used to rescue the intuition that management is more amenable to ethical understanding than MacIntyre himself is willing to acknowledge.

\section{INSTITUTIONS}

In this section I will outline the essential relationship between practices and institutions before going on to argue that because of the cognitive closure of practices, the 
best hope for a substantive and general application of MacIntyre's work to business ethics will focus on regulation. In order to do so, I will critically examine Moore's recent attempt to provide an account of MacIntyrean governance measures that aims to 'crowd in' the virtues. Using MacIntyre's account of virtues and practices, Moore suggests eight desiderata through which virtue might be 'crowded in' in the workplace. I will argue that Moore's account is mismatched with MacIntyre's account of moral education, and will go on to argue that a negative approach, an approach that aims to remove obstacles facing practice-based communities, is more likely to succeed than the positive account offered by Moore. Some of the items on Moore's list make sense only within practice-based work, and some make sense only outside practice-based work.

MacIntyre's pessimism about the possibility of institutionally sustaining practicebased work within contemporary society is very real. Such pessimism lends a prima facie plausibility to Gregory Beabout's claim that MacIntyre "has done little to develop an account of practical wisdom as a virtue helpful for those . . charged with managing institutions that house social practices" (Beabout 2012: 419). Beabout goes on to elaborate his own account of what managerial excellence involves. The crucial feature of management, according to Beabout, is that it requires practical wisdom:

In order to become excellent at managing, it is necessary to develop a set of character traits; chief among these is the virtue of practical wisdom. Practical wisdom is the habit of mind whereby one is excellent in each case at finding the available means to accomplish a worthy end. (Beabout 2012: 427)

Practical wisdom is a virtue that is required to act excellently in any context. Aristotle claims that practical wisdom is extensionally equivalent to virtue, so it will no doubt be required by virtuous managers as it is required by all virtuous agents. Management does not call for practical wisdom as a virtue any more than any other complex role. Indeed, the practical wisdom required by Beabout's account of management is rather like the virtues MacIntyre regards as being essential to politics.

Beabout says MacIntyre claims "that institutions have "all the characteristics of a practice" (MacIntyre 2007: 194), but what MacIntyre actually says is that "the making and sustaining of forms of human community - and therefore of institutions_-itself has all the characteristics of a practice" (MacIntyre 2007: 194). The emphasis is therefore on forms of human community. The key point here makes sense only if we first understand the contrast MacIntyre draws between institutions and practices.

Institutions, so MacIntyre argues, are primarily concerned with external goods, whereas the defining characteristic of practices is their internal goods. Therefore MacIntyre's point is that sustaining institutions which allow humans to cultivate the virtues and to achieve their good is a practice, and so managers who sustain these kinds of institutions will be engaged in a practice. The sustaining of institutions in and of itself, or the sustaining of institutions that frustrate people's attempts to achieve their good, that are oppressive, or are merely acquisitive, cannot be a practice. Practices always require some kind of institutional support, such as a school, 
an orchestra, or indeed a business organization. In the cases in which external goods are a necessary end, the practice in question must be carefully managed to avoid the loss of focus on internal goods, but the pursuit of external goods for their own sake is not in itself conducive to virtuous flourishing. The name MacIntyre gives to the practice of institutionally sustaining communities is politics (MacIntyre 2007: 195), which has been a central theme in MacIntyre's work. So, contrary to Beabout's assertion, MacIntyre has devoted much of his life's work to providing an ethical framework which might prove 'helpful' to those who aim to sustain practice-based forms of human community.

Note that the sense of 'politics' as employed by MacIntyre is somewhat idiosyncratic. Politics for MacIntyre is not to be confused with the large-scale politics, which too often amounts to jostling for power, characteristic of the political parties in modern nation states, but is instead a matter of local communities pursuing their common goods (MacIntyre 1999). "Politics is, then, a second order practice: its goods are those of deliberation about practices. . . Its activity is common practical reasoning about the common life" (Murphy 2003b: 163). Given the difficulties inherent in attempting to formulate a general business ethics based on MacIntyre's work, it seems that the most promising direction for attempts to apply MacIntyre's ethical theory within a business ethics context is that of institutionally sustaining workplace communities, which may be what 'managing excellently' amounts to. Although as a kind of meta-practice there is something procedural about politics not found in ordinary practices, it still possesses a rich moral core in that it aims at human good and the avoidance of harm. In the words of Lutz, the "community member becomes excellent as a human agent, and lives the good life for humankind by cultivating virtue and seeking good within human relationships" (Lutz 2012: 148).

Insofar as managers sustain forms of human community against the corrupting power of external goods, then they are practitioners engaged in the meta-practice of politics. This suggests that institutional policies have an important part to play in developing morally educative workplaces in accordance with MacIntyre's concept of practices. The concept of a practice is such that anyone fully engaged in a practice, and therefore motivated by pursuit of the goods internal to that practice, will need the humility and honesty required to subordinate themselves to the appropriate standards of excellence, as well as superior fellow practitioners, and to engage in the continued conversation about the goods and ends of the practice in question, if they are to learn what they must. In this sense, practices can be extremely demanding, not to mention time-consuming. Such demandingness suggests that the concept is probably not applicable to most workplaces. Where job commitment is low, as it is in at least one in four cases (Hafer and Martin 2006), such engagement is almost certainly impossible. But even where commitment is high, the work may not be characterized by internal goods, or allow for the systematic extension of our conceptions of those goods required for practice-status.

We might wonder how someone can come to genuinely engage in a practice. MacIntyre gives the example of a chess-playing child to illustrate this. What is important in MacIntyre's example is the process through which that child comes to understand the goods internal to chess (MacIntyre 2007: 188). Categorically chess 
is a practice, but the child initially plays to be rewarded with candy, i.e., an external rather than an internal good. MacIntyre says that in time the child will come to value the goods and excellences internal to chess, "the achievement of a certain highly particular kind of analytical skill, strategic imagination and competitive intensity" (MacIntyre 2007: 188), and play for those goods rather than external reward. MacIntyre gives another example, that of fishermen who "may well have initially joined [the crew] for the sake of their wage ... but have acquired from the rest of the crew an understanding of and devotion to excellence in fishing" (MacIntyre 1994: 285), and this understanding and devotion are only possible once the fishermen have been properly initiated into the practice. These examples show that people do not need to seek out the practice in advance in order to be able to come to appreciate its internal goods. Employees may initially require supervision and direction before they are eventually able to understand the goods present in their roles (for a fuller discussion of this process, see Newton 1992: 358-60). However, just as it is possible to imagine someone coming to be surprised by the internal goods of an activity that they initially valued for its external rewards, it is also possible to conceive of the proto-practitioner never coming to be motivated by internal goods.

In a world in which every chess grandmaster were motivated only by money and prestige, chess would still possess the features required for practice status, but none of the great chess players would be genuinely engaged in that practice: they would have no reason not to cheat, and no reason not to abandon chess if greater external rewards were available to them elsewhere, and so would miss out on the intrinsic joys of chess as well as the opportunity to cultivate the virtues. This obscuring of internal goods is a danger whenever practices are not adequately safeguarded by institutions. Because it is the nature of institutions to seek external goods, "the ideals and the creativity of the practice are always vulnerable to the acquisitiveness of the institution" (MacIntyre 2007: 194). The upshot of this is that, as Knight puts it, from the "perspective of individuals qua practitioners, the causal order constituted by a practice and an institution is in good order insofar as the goods pursued by the institution are deployed to subserve the good internal to the practice" (Knight 2008: 319).This aim, despite MacIntyre's opposition to corporate modernity noted at the outset of this paper, is clearly possible for business organizations to achieve. A well-ordered institution in this sense will afford its employees a chance to develop the virtues by sustaining practices, and so excellence in management — management that uses practical wisdom to safeguard a practice-will constitute an excellence in politics.

Practices cannot survive without institutions. But unless those institutions are in good order, practices can easily become corrupted by the lure of external goods. Where the institutions are in good order, practitioners can be motivated by the goods internal to practices and the danger of moral failure will be diminished. Moore, in his "The Virtue of Governance, the Governance of Virtue" (2012), attempts to develop an account of institutionalization that is conducive to practices and it is to his account we now turn. Moore succeeds in outlining features that can help to create good organizations in a general sense, but many of the items on his list do not sit as easily with MacIntyre's thought as Moore supposes. In what follows I will 
outline the eight features of Moore's account of governance and put forward some suggestions about the challenges they face if they are to be genuinely compatible with MacIntyre's account of moral education.

1) A focus on the purpose of the organization rather than the bottom line. Moore says, "At the most senior level of governance discussions there will be a need to address the goodness of purpose of the organization which is the extent to which the internal goods of the practice are at the core of the organization" (Moore 2012: 309). However, this policy can apply only where these differ. Organizations which are primarily concerned to maximize income tend not to advertise that fact, so we would expect to see the rhetoric of purpose even where the focus is on profit maximization. Where this measure is genuinely applicable, and where the organization has a good purpose, this is a sensible policy, even if it is possible for an organization to pursue a good aim without treating its employees well, and certainly without providing them with good jobs that can be accurately described as practices.

2) That governance systems require people with pro-social intrinsic preferences. Character assessment and development is crucial, and virtuous candidates should be given jobs. After appointment, character should continue to be nurtured. While virtuous people are indeed to be preferred to vicious, and are more likely to focus on internal goods, it is difficult to imagine this requirement as a workable governance policy because it suggests that the appearance of virtue, the ability to charm, counts for too much. Decisions about whether someone is truly virtuous tend to require more time and experience than is available to those in charge of appointments. Practice-based communities will benefit from being long-lasting and characterized by regular interactions. Furthermore, practices are the schools of the virtues, so practice-based work is supposed to enable those engaged in it to develop the virtues. Practices, when they are in good order, can morally educate us, they do not require that we are virtuous in advance of engaging in them even if the exclusion of the truly vicious is prudent.

Outside of practices however, where organizations are unlikely to be molders of character, this is a sensible policy. Generally the virtuous are more likely than the vicious to be cooperative and conducive to happy, collegial, working environments. Although even then it is more feasible as a policy about internal promotions rather than external recruitment. The selection of virtuous individuals is certainly to be encouraged the more power a role carries. As Newton says, the first precept of business ethics ought to be "not a command to reason correctly from sound principles, but to put good (virtuous) people in positions of responsibility" (Newton 1992: 363). However, genuine practice-based communities emerge organically, and when they do they can motivate people to have pro-social preferences.

3) Job design. In outlining this requirement Moore says "attention needs to be given to job design, so that intrinsic motivation is built in to the greatest extent possible" (Moore 2012: 309). This measure should not apply equally to practice-based and non-practice-based work. Much contemporary work is characterized by 'flexible specialization' (Sennett 1998) which is antithetical to the specialization required by a deep engagement in a particular practice. Excessive flexibility, of the kind that requires significant changes to the focus of a job role, rules out engagement in 
a practice because such engagement is typically demanding and time-consuming. 'Dynamic' organizations are thus prone to deny employees the time and reflective space needed to seriously engage with a practice and realize its internal goods. If our understanding of the goods and ends of a particular activity is to be extended, then it is likely that we will require time to master the activity and to reflect on its goods and ends. Job design is likely to be important in creating virtuous organizations, however, it is non-practice-based work that most requires a focus on job design, as such work is less likely to be intrinsically rewarding. Where work is not intrinsically rewarding, measures such as job rotation or job enrichment will be welcome. Such measures would be odd in practices such as physics, painting and farming, to continue with MacIntyre's own examples. This is because these activities so obviously have internal goods that any significant attempt to 'design' them will often be either unnecessary or intrusive. This is not to say that job design is never appropriate within practices, but that it is considerably less so, and that this marks an important asymmetry between practice-based and non-practice-based work. A more significant focus on job design outside of practices, on the other hand, where the toil is more likely to be alienating and deadening, can help prevent work that lacks rich internal goods from being too much of an unwelcome burden on employees. Moore's account provides a theoretical basis that might prevent particular workplaces from getting worse, and might also help non-practice-based work to improve, but it seems to lack the additional richness of MacIntyre's account of practices.

4) Fixed and fair salaries, a policy that helps the rank and file avoid the conclusion that the senior figures within an organization are concerned solely to achieve large bonuses. As a general principle this is a good one, and sits well with MacIntyre's requirement that large degrees of inequality be avoided on the grounds that such inequalities are liable to produce undue deference that is inimical to genuine communal relationships (see MacIntyre 2006: 39).

5) Use of decision making procedures that strengthen both participation and self-governance. We can broadly agree with Moore about this within practice-based work, but while self-governance is ultimately necessary for a full engagement in a practice, it should not always be an aim outside of practices. In light of the 2008 financial crisis, banking is an instructive example of why this is so: self-governance, where institutional acquisitiveness dominates, will not incentivize virtue and may well facilitate vice. Participation in decision making processes is also valuable, but within practices there are inevitably master-practitioners and beginners, and those beginners may not yet understand the practice well enough to know how the institution might best serve the internal goods of the practice. During tough times a practice-based institution might need to make some changes that increase efficiency at some cost, hopefully temporary, to the ability of practitioners to adhere to the standards of excellence internal to that practice. Exactly which compromises remain compatible with a genuine engagement in the practice will require an expert knowledge that might set limits to the appropriate degree of participation of the beginners. Deliberation should be widespread, but decision-making cannot be egalitarian within a practice. 
6) Low levels of legal contractual enforcement. The purpose of this governance measure is to allow trust to flourish. We should note that this cannot be an explicit governance aim because we cannot draw up a code of conduct that obliges us to avoid having to implement that code of conduct (or at least we cannot do so sensibly), but it might be a good way of measuring the success of an institution. Those engaged in a practice will be motivated by its internal goods, and within practices the relationships between practitioners are defined by the virtues, so there is likely to be low levels of such enforcement. It would not need to be an official policy. Outside of practices, however, low levels of contractual enforcement might be replaced by self-surveillance, as illustrated by Barker (1993), who found that allowing teams to be self-managed can result in "a form of control more powerful, less apparent, and more difficult to resist" (Barker 1993: 408) than in traditional forms of bureaucracy. Where institutions treat staff badly, and there is pressure to work long hours or to ignore safety legislation, high levels of contractual enforcement will be welcome. Indeed, as I argue below, regulation can be used to support practice-based communities.

7) Encouraging group identity. According to Moore, this is a fairly natural result of implementing the previous six measures. However, the attempt to implement such measures can lead to what Irving Janis called 'Groupthink' - "A mode of thinking that people engage in when they are deeply involved in a cohesive in-group, when the members' strivings for unanimity override their motivation to realistically appraise alternative courses of action." (Janus 1972: 9) This is clearly inimical to virtuous flourishing and would undermine the morally educative nature of practices, but even where groupthink does not obtain, the demands of such thorough-going emotional labor are quite worrying in themselves. Some kind of group identity is inevitable when a group of people have subordinated themselves to the same standards of excellence, as any group of practitioners have done. In this case it is likely to be unnecessary within a practice. Outside of such groups it is not clear that group identity is desirable. ${ }^{6}$

8) Transparency. This again is something that flows from the other measures, according to Moore, and something few business ethicists would oppose. There is of course a sense in which practices are necessarily opaque, but transparency in terms of institutional procedures is a good aim.

What are we to make of Moore's list as a whole? In most cases there is something clearly right about Moore's suggestions, but in most cases too the most appropriate response seems to vary with the status of the kind of work as practice-based or non-practice-based. Moore makes no such distinction. However, this distinction between practices, non-practices, and the meta-practice of politics means we need a multi-faceted account of work if we are to apply MacIntyre's ethical theory. Generally, Moore's measures are good candidates for a system of governance that helps to create a moral climate, which, in light of challenges to virtue ethics inspired by the results of personality psychology ${ }^{7}$ is an important aim, but this is rather different from his aim of creating a system of governance based on MacIntyre's account of practices and virtues. Despite the merits of Moore's account, as it stands it lacks the additional richness of MacIntyre's ethics. ${ }^{8}$ 
Moore's attempt to develop an account of governance that emphasizes goods internal to practices, reflects a laudable but, given the cognitive closure of practices, deeply problematic aim. The fact that experience is required for judgment within practices, as we noted above, means that a unified and uniform account of governance simply cannot capture very much of MacIntyre's positive ethical theory, i.e., that part of his ethical theory concerned with what is good or how we can acquire the virtues, and that necessarily goes beyond behavioral compliance. Reliable judgments about internal goods require a deep and thorough knowledge of the practice in question, and so cannot be built into generic governance measures. The wider the intended application the more diluted the ethical pronouncements. An institution could possess many, perhaps even all, of the items of Moore's list and yet still fail to be conducive to flourishing because the work carried out therein failed to be as rich and rewarding, as practices are (e.g., 'Turnip Planting Co.,' management consultancies - though both can be more or less virtuous, they would lack the distinct internal goods to be morally educative in MacIntyre's sense). Because the effectiveness and appropriateness of Moore's eight suggested measures varies depending on whether the kind of work carried out within an organizations is practice-based or not, the appropriateness of such measures will require empirical investigation.

As we noted above, one of the consequences of the fact that each practice has distinct internal goods is that those with no relevant experience are unqualified as judges of them. In this sense, practices are cognitively closed. Given the particularities of any organization, effective systems of governance are likely to be highly context dependent. Within practices, each of which have distinct internal goods fully known only to those who have mastered them, this specificity is likely to be vastly greater. The exact conditions under which a community of fisherman can and cannot devote themselves to the internal goods of fishing is something that can be best decided by those with relevant experience, and any practice and any community of practitioners will need to discover its own way of governing the institutions that sustain the practice in question. This is not to deny that economic circumstances may sometimes require that compromises between the pursuits of internal and external goods must be reached, but that any compromise compatible with genuine practice engagement, and the possibility of moral education that entails, will require the inputs of the initiated. As such, they will vary across practices.

In attempting to show how workplaces can be made to accord with MacIntyre's ethical theory, it seems that Moore is attempting to get too much out of an account of governance. Although it might be possible to devise a system of governance that minimizes vice, no amount of institutional reform can transform work that is not characterized by complex internal goods into a practice. Once we recognize this we might wonder whether MacIntyre's work can have any meaningful general application to the contemporary workplace. It can, but it must take a rather surprising form: that of regulation.

An account of regulation that aims to be an application of MacIntyre's ethics will be an account that, instead of aiming to ensure that work is conducive to virtuous flourishing, aims at preventing the more serious threats to flourishing at work. Moore considers a merely regulatory approach to be "too shallow for the prescription to be 
effective in the long term. It is, in other words, governance without ethics" (Moore 2012: 301). We can agree with Moore in this judgment about a merely regulative approach. Such approaches are unlikely to contain the features we desire in a positive account of ethics, and this is especially so in cases of practice-based work. However, because his account fails to distinguish between measures appropriate to institutions that house practice-based work and measures appropriate to those which do not, and because no over-arching account of governance can do justice to the particularities of individual practices, we may well feel compelled to make a similar judgment about Moore's own prescription as it currently stands.

\section{REGULATION AND MANAGEMENT AS POLITICS}

MacIntyre's account of moral education, based as it is on his concept of a practice, will resist any attempt to positively apply it to business ethics in any general way. But this does not mean it can have no application: accounts of whether particular activities are to be accounted practices remain valuable. Nor does it mean there can be no negative general application of MacIntyre's ethics, i.e., an application that, rather than focusing on goods internal to practices and to the virtues, focuses instead on preventing threats to practice-based communities. As we saw above, MacIntyre's conception of politics is deeply at odds with how that notion is commonly understood. MacIntyre's discussions of politics not only center on small, practice-based communities, they make it clear that he is hostile to large-scale politics characteristic of modern nation states. Given that, it is unsurprising that MacIntyre himself also has a fairly low opinion of regulation. MacIntyre's positive ethics, like any Aristotelian ethics, extends beyond mere behavioral compliance, and therefore it may seem surprising that this paper ends with a discussion of the ethical potential of regulation. In this section I will argue that there is greater scope for regulation to facilitate MacIntyre's ethics than might at first glance seem to be the case. Even if we are pessimistic about the possibility of business organizations housing genuinely practice-based communities (I take it that this is an open question, and one that is perhaps only to be answered empirically), there is still scope for regulation, and ultimately management when conceived of as a meta-practice, to support practice-based communities.

MacIntyre specifies certain necessary conditions for a political or social institution to be conducive to the achievement of individual and common goods. He says:

They must afford expression to the political decision-making of independent reasoners on all those matters on which it is important that the members of a particular community be able to come through shared rational deliberation to a common mind. (MacIntyre, 1999: 129)

For MacIntyre, it is only under such conditions that a substantive conception of the common good is possible: only in small scale communities can there be a politics that is not dominated by competing interests. Where fundamentally different interests do compete, rational persuasion is secondary to leverage in negotiations and the ability to manipulate others becomes crucial. MacIntyre says, "The practice of the virtues 
... is something difficult to reconcile with functioning well in the present economic order." (MacIntyre 2008: 6) This is because MacIntyre regards the systematic exclusion of practices and the overwhelming emphasis on pursuit of external goods as being characteristic of the dominant institutions of modernity, in particular the market economy and individual corporations. This is where regulation comes in.

Regulation may be too ethically shallow to be genuinely morally educative but it may also be the most prudent and effective way to ensure serious ills are averted in the workplace. More than this it might facilitate the existence of practice-supporting institutions and therefore practice-based communities. Outside practice-based communities regulation is necessary. MacIntyre illustrates his point with reference to the thalidomide case, during which a drug prescribed to treat morning sickness in pregnant women was found to cause birth defects.

What then are we to say of regulation? When we are concerned with those regulations that deal with the quality and safety of goods and services, we ought to be clear that we need regulation only because human nature is gravely defective when embodied in the modem corporation - regulation, remember, applies primarily to the activities of corporations and only secondarily to the activities of individuals. . . Think of the thalidomide case. .. . What Grünenthal Chemie in Germany and what the Distillers Corporation in Britain were willing to do, as the developers and the licensees for thalidomide, shows very clearly that large corporations are collectively quite willing to undertake courses of action that individuals in the corporation would be deeply shocked by if it was proposed that they as individuals should do what the corporation does. The individuals who staff Grünenthal or Distillers are generally no worse than the rest of us. It is simply the case that in a corporate society one of the ways in which moral relationships have been eroded is by the substitution of corporate for individual responsibility. (MacIntyre 1980: 33)

Regulation is thus a substitute for morality, according to MacIntyre. However, regulation has the potential to be an ally to MacIntyre's ethics because it is possible to regulate governance procedures so that any that threaten practices are definitively ruled out. Sometimes regulation simply appears to be the enforcement of commonsense (e.g., rules about wearing hardhats on building sites), but even here it might stand in for prudence. To note this should not, however, blind us to the fact that where rational argument and persuasion, and thus communal agreement, are impossible our response ought to be: 'three cheers for regulation.' Indeed, MacIntyre admits it is the best we can do given the moral culture we inhabit (MacIntyre 1980: 33), a culture which MacIntyre regards as inimical to the virtues. Practice-based communities are able to do better because members share premises, which allows for meaningful collective deliberation, but outside of practice-based work-and therefore in very many ordinary workplaces - there is substantially less chance of significant communal agreement, and therefore of the moral education and intrinsic rewards that are the focus of the concept of a practice.

In attempting to bring about MacIntyrean regulatory measures that can best protect and perhaps even encourage flourishing in the real world, we must recognize that "Moral education will be ineffective if it sets too high a standard too quickly" (MacIntyre 2006: 47). Policy, at both corporate and governmental levels, should 
therefore concern vices that undermine social life and harm others, rather than the inculcation of virtue. Positive ethics should be left to communities of practice where people share premises and can therefore meaningfully deliberate. ${ }^{9}$ Regulation then is not simply a substitute for morality. When it is devised excellently, it can be a negative facilitator of morality even if it cannot directly foster a positive ethics (though we might more optimistically note that regulation could lead to certain habits which could, in due course, become virtues).

Aquinas, whom MacIntyre approvingly quotes, gives the examples of murder and theft as the sorts of crimes that most seriously undermine social life. Although hardly rivals to stress and absenteeism as workplace problems, it is instructive to consider Aquinas's reasoning. Aquinas would disagree with both puritans and liberals: "Like those puritans and unlike those liberals, he understands the law as an instrument for our moral education. But, like those liberals and unlike those puritans, he is against making law by itself an attempt to repress all vice" (MacIntyre 2006: 47). Note that the focus here is not on the vicious, it is on the security of the knowledge that one is very unlikely to be murdered and that one's property is relatively protected by the law. The intended result is that people need not worry excessively about crime. If we apply this model to the workplace, regulation can suppress threats to the internal goods of different kinds of work, but it cannot aim at being positively morally educative. Absence of effective regulation can hinder organizations that have good aims by creating a 'race to the bottom' whereby pressure to be competitive forces such organizations to focus more on the pursuit of external goods rather than the purpose of their organization. Practice-based organizations will benefit most from effective regulation, as they will be less inclined to cut corners in pursuit of external goods than those organizations are not practice-based. Where practitioners can pursue internal goods relatively unimpeded by the threat of corruption by institutional pursuit of external goods, regulation will have been sufficient. Regulation cannot provide a meaningful moral education by itself, it can merely provide a platform for it but helping to support organizations which do. No one organization has the power to unilaterally curtail the most serious threats to its internal goods, but provided with a regulatory platform institutions that house practices are more likely to achieve their goal of properly supporting that practice.

Those sympathetic to MacIntyre's work are likely to find this conclusion counterintuitive, nevertheless regulation has the potential to be a more valuable tool than it might appear. Although the externality of what has been called the 'modern liberal regulatory agenda' (Arnold 2009) means that it cannot foster internal goods, as long as its aims are predominantly negative this is not problematic. Indeed, the very externality of regulation is its chief advantage. For one thing, regulation might be more reliable than governance because a regulator is less likely to be subject to pressure to cut corners in order to achieve greater external rewards (though not entirely immune to the possibility of corruption, clearly). Despite his hostility to large scale politics, MacIntyre has admitted that prudence dictates that local communities sometimes engage with the nation state because doing so is often the only way to secure the goods they need (MacIntyre 2010). Large-scale politics can support community-based politics, and business regulation (and law more generally) can support practices that 
are housed within business organizations. Accounts of governance will face serious challenges when trying to capture much of MacIntyre's ethics because MacIntyre's ethics resists adequate capture by any such general rules. Where general rules can support an ethical theory which focuses on practice-based communities is one step further removed from practices and communities themselves.

Furthermore, well-conceived regulation can help genuine practitioners and organizations which house practices in other ways. Accreditation to a regulatory body can help practitioners to receive due recognition and reward because it can give the uninitiated (for instance, potential customers) confidence in the institution that houses those practitioners. The uninitiated are not qualified to judge the testimony of experienced practitioners, and so will rely in certain cases on accreditation by external bodies. We are all, dentists and patients, better off for the existence of regulatory bodies governing dentistry. Regulation can therefore provide a minimal level of public trust that practice-based businesses will require. This means that even excellently conceived and implemented regulation cannot promote moral education directly, it can play an important role in safe-guarding communities of practice, in this case business organizations that house practices, against external threats. In this way, there is a case for conceiving of even large-scale politics as a kind of meta-practice (or perhaps meta-meta-practice). As we saw above, MacIntyre's conception of politics is of a meta-practice that facilitates deliberation about goods within a community. Large-scale politics might too be a kind of meta-practice, the practice of sustaining the meta-practice of 'politics' in MacIntyre's sense ${ }^{10}$ - the politics of local communities-by protecting them from harm through well-chosen legislation. However, even if there is any compelling reason for thinking that largescale politics cannot be a meta-practice, regulation remains valuable for its power to protect communities of practice.

We find ourselves in a position to agree with Aristotle, who thought that while there should be some ethical rules that prohibit absolutely wrong actions (see Nicomachean Ethics 1107a5-15), the positively good is a matter of appearing to be choice-worthy to virtuous agents. The positively good is sufficiently context dependent that it cannot be adequately captured by rules, though rules remain necessary to eliminate threats to that good. Similarly we might seek to ameliorate non-practice-based work, but if we regard practices as offering the best way of understanding the potential of work to be both intrinsically rewarding and morally educative, we need to realize that general applications of MacIntyre's positive ethical theory are likely to fail. The arguments I have advanced suggest that, while those who safeguard practices and practice-based communities do important work, the methods by which we can make work good cannot be solely managerial. Any attempt to deal with non-practice-based work must focus partly on the politics of work rather than solely on workplaces, and any attempt to develop an account of practice-based work must focus on the details of particular practices. The cognitive closure of practices, and the contextual knowledge required to govern a particular practice or community of practitioners show that stringent regulation is the best hope for ensuring that most workplaces (at least in contemporary society) are not too incompatible with MacIntyre's ethics, even though it cannot foster the good in a positive sense. 
So if regulation can be salvaged, can management also? The answer to this question is not straight forward. While the aim of creating good workplaces cannot be solely managerial, it can be partly managerial, especially outside of practices. To see why this is so, let us return to the issue of community. MacIntyre is at pains to point out that community is not intrinsically valuable. It is valuable because it allows for the collaborative pursuit of various common goods. Such community is likely to be unavailable at the level of entire firms. Large firms are usually dispersed across many individual workplaces. Someone might be able to identify a common good with the members of their department, that is people with whom they have daily face-to-face contact, but it is harder to imagine this relationship obtaining between people whose only contact is via email. The goals of a large company are likely to be too vague or diverse to ground a deep sense of common enterprise, and in an era of flexible specialization companies are liable to change over even short periods of time. Indeed the sheer size of such companies is an obstacle, but this is not so at the level of team or department, and it is not necessarily so of small companies which plausibly possess the requisite homogeneity of purpose. This means that management per se is not as important a complement to good regulation as managers themselves are. Organizations which house work that is not practice-based may not be capable of accommodating the deliberation characteristic of fully practice-based communities, as employees in such organizations are unlikely to share premises. However, virtuous managers can help to create a cohesiveness conducive to a sense of community.

Work that is not generally practice-based is not, on MacIntyre's view, an education in the virtues when considered as a particular activity, and so workplace communities are unlikely to be molders of character in the same way that paradigmatic examples of practice-based communities are. However, when seen as a collaborative challenge and as a challenge to maintain community and solidarity in the face of institutional pressures, work within a contemporary organization can provide such an education. Even in a highly acquisitive institution in which the work carried out lacks internal goods, there remains the possibility of a community of sorts. While this community might generally be best protected by apt regulatory measures, the matter of day to day conduct is not adequately covered by such regulation. This is where management comes in: management as politics. MacIntyre's emphasis on the small-scale and face-to-face interactions is partially echoed in recent work on management by Henry Mintzberg, whose suggestions that the selection and promotion of managers should partly depend on the opinion of those who have been managed by them (Mintzberg 2009: 220) and that managers are not in themselves effective but only matches between managers, particular institutions, and particular working groups are effective (Mintzberg 2009: 222) sit more easily with MacIntyre's moral philosophy than any attempt to devise MacIntyrean accounts of management or corporate governance.

Politics in MacIntyre's sense requires virtues such as prudence, diligence, justice as without those virtues, participation in any practice or community will be threatened. Work within contemporary organizations can, when the relationships within them are allowed to develop over time, and when the relationships possess a degree of security, become sites of genuine deliberation and pursuit of common goods. So 
while, as I argued above, MacIntyre's positive ethics resists any general and positive application along the lines of a theory of good management or the governance of virtue, the nature of human communities entails that virtuous managers are an important complement to a political, regulatory order that aims to serve practice-based communities. While management, like politics, is inevitably partially concerned with power — an external good — and might seem to be adversarial in a way that ordinary practices are not, this does not present an insuperable problem. Ordinary practices too can become corrupted, and can become excessively adversarial. Above, I gave the example of chess grandmasters motivated solely by external goods. Such chess players would not genuinely be engaged in the practice of chess, and any manager or politician who proceeds in an entirely adversarial manner will be unable to properly protect a practice-based community. Chess players who seek to vanquish opponents above all else are unlikely to achieve the goods internal to chess, just as managers who primarily focus on external goods are unlikely to virtuously support practice-based workplace communities. Management might be inherently more prone to corruption than chess, which is why it will be well served by judicious regulatory measures that might mitigate the corrupting power of external goods. ${ }^{11}$

\section{NOTES}

1. The sources supporting this are too numerous for me to list them all, but see MacIntyre 1979a, 1979b, 1982, 2008 for a representative selection.

2. Briefly, narrative unity requires that one subsume all of one's various commitments under a single 'life-story' in order to achieve the integrity required by moral agency, and traditions are continuing conversations about the nature of practices, goods, society etc.

3. Unlike Aristotle, who thought farming was not a virtuous activity.

4. From Whose Justice? Which Rationality? (1988), MacIntyre's distinction between goods of effectiveness. I retain After Virtue's terminology for the sake of simplicity, and because it is more commonly used in the secondary literature.

5. In addition to his general hostility to corporate modernity, MacIntyre remarks that the connection between being a good person and doing good work "has been lost sight of altogether in the characteristic contemporary workplace" (MacIntyre 2011: 323).

6. Indeed, someone who identifies too whole-heartedly with a work group may struggle to achieve a narrative unity which would allow them to put that role into question if and when doing so become necessary.

7. Some recent philosophical accounts of the ramifications of personality psychology suggest that character traits are either non-existent (see Harman 1999) or their use in moral philosophy is irredeemably flawed (see Doris 2002), and that situational factors rather than moral characteristics determine our behavior. Defenders of virtue ethics (for instance, Athanassoulis [2000]), have replied that such results should be taken to demonstrate that genuine virtuous possession is rare and requires a good deal of support, rather than impossible.

8. Chen, Sawyers, and Williams (1997) argue that good ethical decision making within corporations depends on the ethical climate of the organization more than the qualities of the agents. Moore's view is compatible with this approach, MacIntyre's necessarily goes beyond it.

9. Something like this dualism is present in Timothy Chappell's argument for a version of liberalism in his "Utopias and the Art of the Possible" (2008). There Chappell argues that 'bureaucracy's' neutrality is not the sign of a moral vacuum, but is rather its moral strength, for it makes possible the pursuit of various communal goods that MacIntyrean political philosophy has always been at pains to prioritize.

10. Though the fact that contemporary large-scale politics is pre-occupied with the pursuit of external goods means there are relatively few politicians engaged in such a meta-practice.

11. I would like to thank Prof. Kenneth E. Goodpaster and three anonymous referees at BEQ for their helpful comments on previous versions of this essay. 


\section{REFERENCES}

Aristotle. 1999. Nicomachean Ethics. Indianapolis: Hackett.

Arnold, N. S. 2009. Imposing Values . Oxford: Oxford University Press. http://dx.doi.org/10.1093/acprof:oso/9780195374964.001.0001

Athanassoulis, N. 2000. "A Response to Harman," Proceedings of the Aristotelian Society 100: 215-21. http://dx.doi.org/10.1111/j.0066-7372.2003.00012.x

Barker, J. R. 1993. "Tightening the Iron Cage: Concertive Control in Self Managing Teams," Administrative Science Quarterly 38(3): 408-37. http://dx.doi.org/10.2307/2393374

Beabout, G. 2012. "Management as a Domain-Relative Practice that Requires and Develops Practical Wisdom," Business Ethics Quarterly 22(2): 405-32.

http://dx.doi.org/10.5840/beq201222214

Beadle, R. 2002. "The Misappropriation of MacIntyre," Philosophy of Management 2: 45-54. http://dx.doi.org/10.5840/pom2002226

. 2008. "Why Business Cannot Be a Practice," Analyse und kritik 30: 229-41.

Beadle, R., and K. Knight. 2012. "Virtue and Meaningful Work," Business Ethics Quarterly 22(2): 433-50. http://dx.doi.org/10.5840/beq201222219

Blackledge, P., and K. Knight, eds. 2011. Virtue and Politics. Notre Dame, Ind.: University of Notre Dame Press.

Borden, S. 2007. Journalism as Practice. Aldershot: Ashgate.

Brewer, K. B. 1997. "Management as a Practice: A Response to Alasdair MacIntyre," Journal of Business Ethics 16: 825-33. http://dx.doi.org/10.1023/A:1017997200200

Chappell, T. 2008. "Utopias and the Art of the Possible," Analyse und kritik 30: 179-203.

Chen, A. Y. S., R. B. Sawyers, and P. F. Williams. 1997. "Reinforcing Ethical Decision Making Through Corporate Culture," Journal of Business Ethics 16: 855-65. http://dx.doi.org/10.1023/A:1017953517947

Crawford, M. 2009. The Case for Working with Your Hands. London: Viking.

Crisp, R., ed. 1996. How Should One Live? Oxford: Oxford University Press.

D'Andrea, T. D. 2006. Tradition, Rationality and Virtue: The Thought of Alasdair MacIntyre. Aldershot: Ashgate.

Dobson, J. 2008. “Utopia Reconsidered: The Modern Firm as Institutional Ideal,” Philosophy of Management 7: 67-75. http://dx.doi.org/10.5840/pom2008717

. 2009. "Alasdair MacIntyre's Aristotelian Business Ethics: A Critique," Journal of Business Ethics 86: 43-50. http://dx.doi.org/10.1007/s10551-008-9792-2

Doris, J. 2002. Lack of Character. Cambridge: Cambridge University Press.

Du Gay, P. 2000. In Praise of Bureaucracy. London: Sage.

Dunne, J. 2003. “Arguing for Teaching as a Practice: a Reply to Alasdair MacIntyre," Journal of Philosophy of Education 37(2): 353-69. http://dx.doi.org/10.1111/1467-9752.00331

Hafer, J. C., and T. N. Martin. 2006. "Job Involvement or Affective Commitment," Institute of Behavioural and Applied Management 8(1): 2-19. 
Hager, P. 2011. "Refurbishing MacIntyre's Account of Practice," Journal of Philosophy of Education 45(3): 545-61. http://dx.doi.org/10.1111/j.1467-9752.2011.00810.x

Harman, G. 1999. "Moral Philosophy Meets Social Psychology: Virtue Ethics and the Fundamental Attribution Error," Proceedings of the Aristotelian Society 99: 315-31. http://dx.doi.org/10.1111/1467-9264.00062

Horton, J., and S. Mendus, eds. 1994. After MacIntyre. Notre Dame, Ind.: University of Notre Dame Press.

Janus, I. 1972. Victims of Groupthink. Boston: Houghton.

Knight, K. 2007. Aristotelian Philosophy. Cambridge: Polity.

. 2008. "Practices: The Aristotelian Concept," Analyse und kritik 30: 317-29.

Lutz, C. S. 2012. Reading Alasdair MacIntyre's After Virtue. New York: Continuum.

MacIntyre, A. 1979a. "Corporate Modernity and Moral Judgment: Are They Mutually Exclusive?," in Ethics and Problems of the 21st Century, ed. Kenneth M. Sayre and Kenneth E. Goodpaster. Notre Dame, Ind.: University of Notre Dame Press, 122-35.

1979b. "Social Science Methodology as the Ideology of Bureaucratic Authority," in Through the Looking Glass: Epistemology and the Conduct of Inquiry, ed. Maria J. Falco. Lanham, Md.: University Press of America.

1980. "Regulation: A Substitute for Morality," Hastings Center Report 10(1): 31-33. http://dx.doi.org/10.2307/3560503

. 1982. "Why Are the Problems of Business Ethics Insoluble," in Moral Responsibility and the Professions, ed. B. Baumrin and B. Friedman. Notre Dame, Ind.: University of Notre Dame Press, 350-59.

. 1994. "A Partial Response to my Critics," in Horton and Mendus 1994: 283-304.

1999. Dependent Rational Animals. Chicago: Open Court.

2006. Selected Essays, Vol. 2. Cambridge: Cambridge University Press. 2007. After Virtue, 3rd ed. London: Duckworth.

. 2008. "How Aristotelian Can Become Revolutionary: Ethics, Resistance, Utopia," Philosophy of Management 7: 3-7. http://dx.doi.org/10.5840/pom2008712

. 2010. “Two Kinds of Political Reasoning," lecture presented at London Metropolitan University.

. 2011. "Where We Were, Where We Are, Where We Need To Be," in Blackledge and Knight 2011: 307-34.

Mintzberg, H. 2009. Managing. San Francisco: Berrett-Koehler.

Moore, G. 2002. "On the Implications of the Practice-Institution Distinction: MacIntyre and the Application of Modern Virtue Ethics to Business," Business Ethics Quarterly 12(1): 19-32. http://dx.doi.org/10.2307/3857646

2005a. "Corporate Character: Modern Virtue Ethics and the Virtuous Corporation," Business Ethics Quarterly 15(4): 237-55.

http://dx.doi.org/10.5840/beq200515212 
2005b. "Humanizing Business: A Modern Virtue Ethics Approach," Business Ethics Quarterly 15(2): 659-85. http://dx.doi.org/10.5840/beq200515446

. 2012. "The Virtue of Governance, the Governance of Virtue," Business Ethics Quarterly 22(2): 293-318. http://dx.doi.org/10.5840/beq201222221

Muirhead, R. 2004. Just Work. London: Harvard University Press.

Murphy, M. C., ed. 2003a. Alasdair MacIntyre. Cambridge: Cambridge University Press. http://dx.doi.org/10.1017/CBO9780511609961

. 2003b. "MacIntyre's Political Philosophy," in Murphy 2003a.

Newton, L. 1992. "Virtue and Role: Reflections on the Social Nature of Morality," Business Ethics Quarterly 2(3): 357-65.

Sellman, D. 2000. "Alasdair MacIntyre and the Professional Practice of Nursing," Nursing Philosophy 1(1): 26-33. http://dx.doi.org/10.1046/j.1466-769x.2000.00002.x

Sennett, R. 1998. The Corrosion of Character. New York: Norton.

Warren, R. 1996. "The Empty Company: Morality and Job Security," Personnel Review 25(6): 41-53. http://dx.doi.org/10.1108/00483489610148527

Whetstone, T. 2003. "The Language of Managerial Excellence: Virtues as Understood and Applied," Journal of Business Ethics 44: 343-57.

http://dx.doi.org/10.1023/A:1023640401539 